\title{
Geochemical investigation of Neogene volcaniclastic rocks from the south-eastern part of the Zărand Basin (Apuseni Mts., Romania) - implications for locating the source area
}

\author{
Luminița Zaharia ${ }^{1,2}$, Nicolae Har² \& Marius Vlăzan $^{2}$ \\ ${ }^{1}$ Babeş-Bolyai University, Museum of Mineralogy, Kogălniceanu 1, 400084 Cluj-Napoca, Romania \\ ${ }^{1}$ Babeş-Bolyai University, Department of Geology, Kogălniceanu 1, 400084 Cluj-Napoca, Romania
}

Received: September 2015; accepted July 2016

Available online 02 August 2016

DOI: http://dx.doi.org/10.5038/1937-8602.60.2.1287

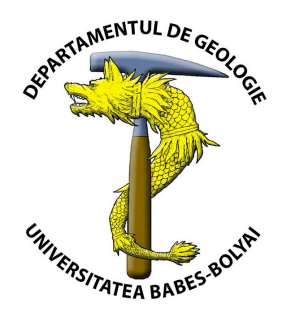

\begin{abstract}
A geochemical study of the Neogene volcaniclastic deposits from the south-eastern part of the Zărand Basin (Apuseni Mts., Romania) was performed. The investigated rocks are represented by medium-K calc-alkaline andesites. Their geochemical features are similar with those of other Neogene volcanic rocks from the Apuseni Mts. However, the investigated rocks also display a few particularities: limited variation of some major oxides and trace elements content, much lower content of $\mathrm{Nb}$ or of light REE. As for the other Neogene volcanic rocks from Apuseni area, the geochemical evidence supports a magma source located close to the boundary between crust and garnetfree lithospheric mantle, minor fractional crystallization processes affecting the magma. A subduction signature was identified for the investigated samples, and, similar to other Neogene volcanic rocks from Apuseni Mts., was interpreted as being related to some enrichment in fluids of the magma source. Based on the location and geochemical similarities with those of other Neogene volcanic rocks from the Apuseni Mts, the assumed age range of volcanic activity generating the volcaniclastic rocks of the study area is $13.8-10 \mathrm{Ma}$, while the source of the volcaniclastic material is most probably the Bontău volcanic structure.
\end{abstract}

Keywords: volcaniclastic rocks, andesites, geochemistry, Neogene, Zărand basin, Apuseni Mountains.

\section{INTRODUCTION}

During Neogene and Quaternary times, an intense igneous activity occurred in Central and Eastern Europe. There is an impressive amount of studies and syntheses regarding the geological, structural, petrological and geochemical characteristics of most of the occurrences, as well as on the various geodynamic implications of magmatic activity occurred within the Carpathian-Pannonian region (e.g., Szabó et al., 1992; Csontos, 1995; Seghedi et al., 2004; Harangi et al., 2006; Pécskay et al., 2006; Harangi and Lenkey, 2007; Seghedi and Downes, 2011). The Neogene magmatic rocks in the Carpatho-Pannonian area are mainly represented by volcanic rocks and, in lesser extent, by intrusive bodies. The petrographical and geochemical characteristics are diverse, ranging from basalts to rhyolites, dominantly calc-alkaline, although alkaline products were also described (as rare K- and ultra-K alkaline and more common Na-alkaline rocks) (e.g., Harangi, 2001; Roșu et al., 2004; Seghedi and Downes, 2011).

The Neogene volcanic products which are located along the Carpathian arc were generated in a convergent setting, as the result of subduction processes (e.g., Csontos, 1995, Schmid et al., 2008). In the same time, in Apuseni Mts., an extensional regim (Balintoni and Vlad, 1998) resulted in an intense, magmatic activity (Roșu et al., 2004, Seghedi et al., 2005). It was assumed that the Neogene magma generation in the Apuseni Mts. was the result of decompression processes (Seghedi et al., 1998; 2005; Roşu et al., 2001, 2004) during eastward translation and rotation of the intra-Carpathian blocks (ALCAPA and Tisza-Dacia) during Miocene (e.g., Ratschbacher et al., 1993; Pătraşcu et al., 1994).

The Apuseni Neogene volcanic rocks are of a special importance, due to the associated metallogenic activity $(\mathrm{Cu}$, $\mathrm{Au}, \mathrm{Mo}, \mathrm{Te}$ or base metal mineralization, e.g. Cioflica et al., 1973; Udubaşa et al., 2001; Cook et al., 2004; Ciobanu et al., 2004). In fact, they are hosting some of the largest porphyry-epithermal $\mathrm{Cu}-\mathrm{Au}$ ore deposits associated with shallow subvolcanic intrusions. To constrain the geotectonic model and melt generation processes, which are responsible for the mineralizing magmatic activity, numerous detailed and complex studies were performed (e.g., Roşu et al., 2004; Harris et al., 2013).

Despite their spatial extension, volcanic products occurring in the south-western part of the Apuseni Mts. (Zărand basin) were investigated to a much lesser degree, as compared with other Neogene igneous areas (e.g., Brad, Săcărâmb or Roşia Montană areas), mainly because this area lacks ore deposits.

As geochemical, isotopic or age data are rather scarce for the volcanic rocks of the Zărand Basin, the present study aims at bringing new data regarding the geochemistry of the pyroclastic material of the southern and south-western part of Zărand Basin (Brazi - Secaş area), especially the trace 
elements geochemistry, as well as to identify the possible source of the volcaniclastic material from the studied area.

\section{GEOLOGICAL SETTING}

In the southern part of the Apuseni Mts. the Neogene volcanic and intrusive rocks occur along a NW-SE-striking 100 $\mathrm{km}$ long area, with reduced spatial development toward NNE (Fig. 1), and were grouped in four separated areas (1) Baia de Arieş-Roşia Montană-Bucium; (2) Zărand-Brad-Zlatna; (3) Săcărâmb and (4) Deva, the latter including the youngest unit, Uroi (Roşu et al., 1997, 2004). The volcanic activity took place between 14.7 and 7.4 Ma, with a last isolated event at about $\sim 1.6$ Ma (at Uroi) (Pécskay et al., 1995; Roşu et al., 1997, 2004). Numerous geochemical, isotopic $\left({ }^{144} \mathrm{Nd} /{ }^{143} \mathrm{Nd}\right.$ and ${ }^{87} \mathrm{Sr} /{ }^{86} \mathrm{Sr}$ ratio), age (K/Ar) and paleomagnetic data (e.g., Pătraşcu et al., 1994; Roşu et al., 1997, 2001, 2004; Panaiotu, 1998; Szakács et al., 1999, Pécskay et al., 1995, 2006) revealed that magma generation and volcanic activity in the southern Apuseni Mts. is age-dependent: the younger the rocks, the more alkaline and more primitive are their magma sources (Szakács et al., 1999; Roşu et al., 2001, 2004; Seghedi et al., 2004).
The Zărand basin and the surrounding mountain areas are the hosts of the largest continuous Neogene volcanic activity in the Apuseni Mts (Fig. 1), in connection with the Békés Basin to the west, in Hungary (Seghedi et al., 1998, 2010). There are few previous studies regarding mainly the petrography and the geochemistry of the volcanic rocks from the Zărand basin (Savu and Neacşu, 1962; Sagatovici and Anastasiu, 1972; Berbeleac et al., 1981, 1992, 1995). The more recent analytical works included, besides geochemical data (major and trace elements, stable isotopes), a few K/Ar age dating results (Pécskay et al., 1995; Roşu et al, 2004; Seghedi et al, 2007, 2010).

Roşu et al. (2004) and Seghedi et al. (2010) published geological, geochemical and volcanological data regarding the Neogene volcanism in Zărand Basin. Roşu et al. (2004) described the presence of two types of andesitic rocks (orthoand clinopyroxene andesite and amphibole \pm pyroxene andesite) with calc-alkaline features. According to Roşu et al. (2004), the whole-rock geochemical and isotopic features of the Neogene volcanic rocks from Zărand Basin suggest a heterogeneous source affected by decompression melting in an extensional tectonic environment.
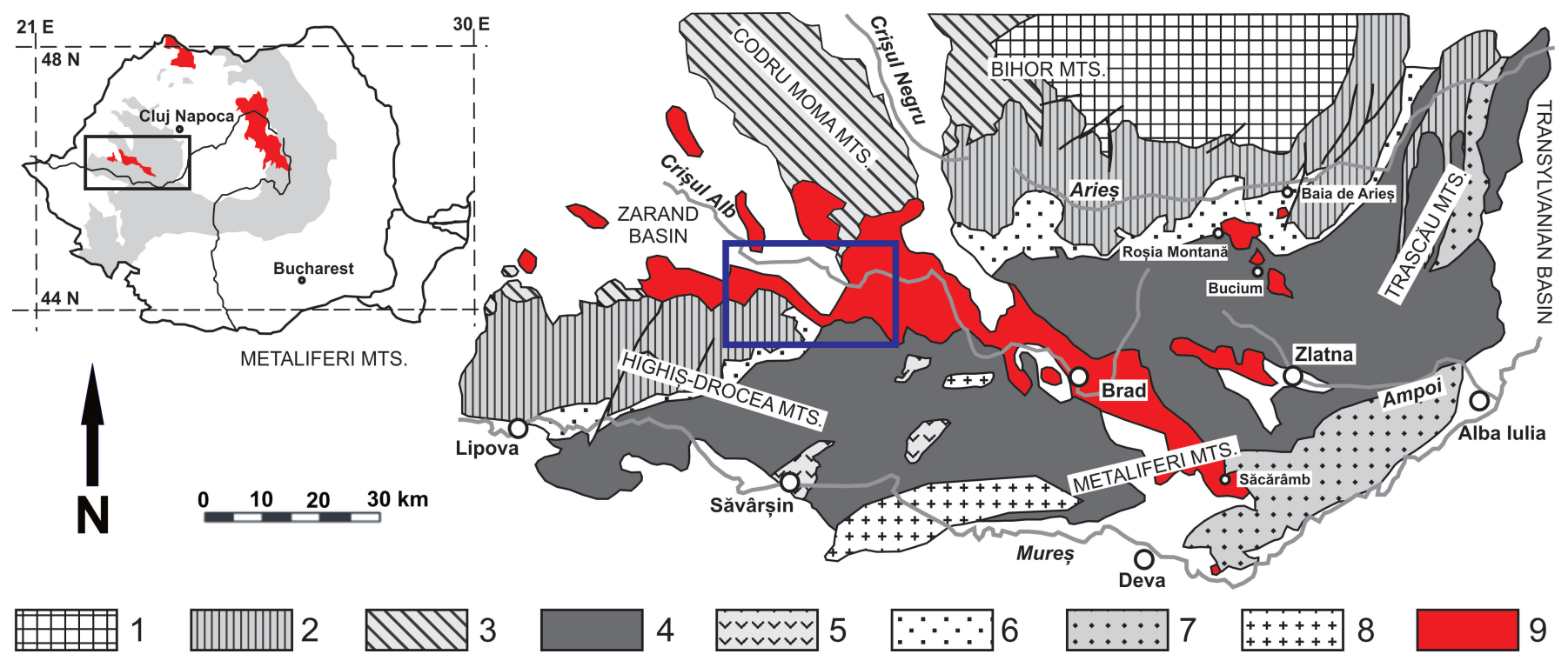

Fig. 1. Sketch of the main tectonic units in the Southern Apuseni Mts, showing the location of the studied volcanic area (blue square) (after Balintoni et al., 2009); the inset shows the occurences of the Neogene volcanic products (in red) and the location of the studied area (black square) on the map of Romania. 1) Bihor Autochthon units (metamorphic rocks and Permo-Mesozoic sediments); 2) Biharia Nappe system; 3) Codru Nappe system; 4) Mureș Zone units (Jurassic and Lower Cretaceous volcanics and sediments); 5) Jurassic granitic intrusions; 6) Turonian-Senonian Gosau-type sediments; 7) Upper Cretaceous flyschoid sediments; 8) Upper Cretaceous-Paleocene extensional magmatites; 9) Neogene volcanics.

\section{MATERIALS AND ANALYTICAL METHODS}

\section{Study area and sample petrography}

The investigated area is located in the south-eastern part of the Zărand Basin (Fig. 1), the clastic material of volcanic origin being studied. The basement consists of Palaeozoic micaschists and paragneises, Mesozoic igneous rocks and Cretaceous sedimentary deposits, covered by Neogene sedimentary and volcanic rocks with associated volcaniclastic deposits (Fig. 2). The magma ascent was facilitated by deep fractures, which resulted during the subsidence of the Zărand Basin (Savu and Neacşu, 1962; Sagatovici and Anastasiu, 1972).

The studied Neogene volcaniclastic deposits are of matrixsupported type (Fig. 3), some with a rough stratification
(Fig. 3a,c), mainly consisting of unsorted, angular clasts (Fig. 3b,d,e). The investigated outcrops are up to $50 \mathrm{~m}$ thick, with high homogeneity in terms of clast distribution. The clasts are variable in size from submilimeters up to $2 \mathrm{~m}$ in diameter (blocks). In the upper part of outcrop No. 2 (Fig. 2), two levels up to $20 \mathrm{~cm}$ thick consisting of volcanic material of lapilli tuff were identified. The presence of the lapilli tuffs as interbedded layers within the coarse volcaniclastic deposit suggests its distal source as compared with that of the host deposit.

Several clasts of various grain size (ranging from 10 to $50 \mathrm{~cm}$ in diameter) from the unsorted volcaniclastic deposit were sampled. Petrographically, two varieties of andesites were observed (Fig. 4): pyroxene andesites (ortho- and clinopyroxene), which are volumetrically dominant, and 


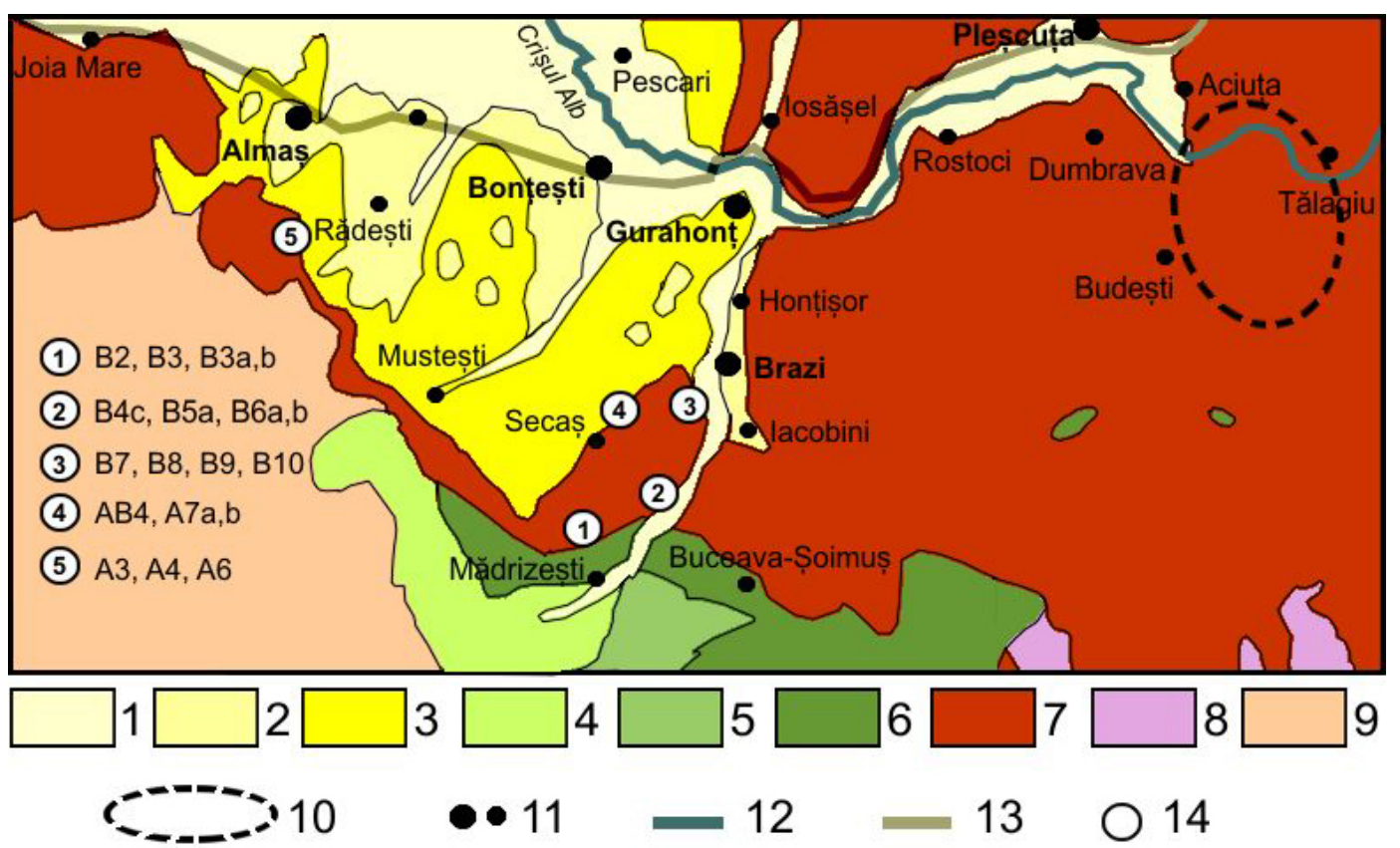

Fig. 2. Simplified geological map of the south-eastern part of the Zărand Basin (Apuseni Mts., Romania), with the location of the investigated samples (according to the Geological Map of Romania, scale 1:50.000, $73 d$ Brad Sheet). 1) Quaternary sands and gravels; 2) Pleistocene deluvial deposits (blocks, gravels, sands); 3) Neogene (Sarmatian-Pannonian) sedimentary deposits (sandstones, limestones, clays): 4) TuronianSenonian Gosau-type sedimentary deposits; 5) Lower Cretaceous (Barremian) sandstones, limestones and conglomerates; 6) Lower Cretaceous (Neocomian) jasps, calcarenites, limestones and conglomerates; 7) Neogene volcanic deposits; 8) Mesozoic and Permian basic magmatites (basalts, diabases); 9) Palaeozoic metamorphic rocks (micaschists, paragneisses); 10) Approximate location of Bontău volcano; 11) Localities; 12) Rivers; 13) Roads; 14) Sampling points.
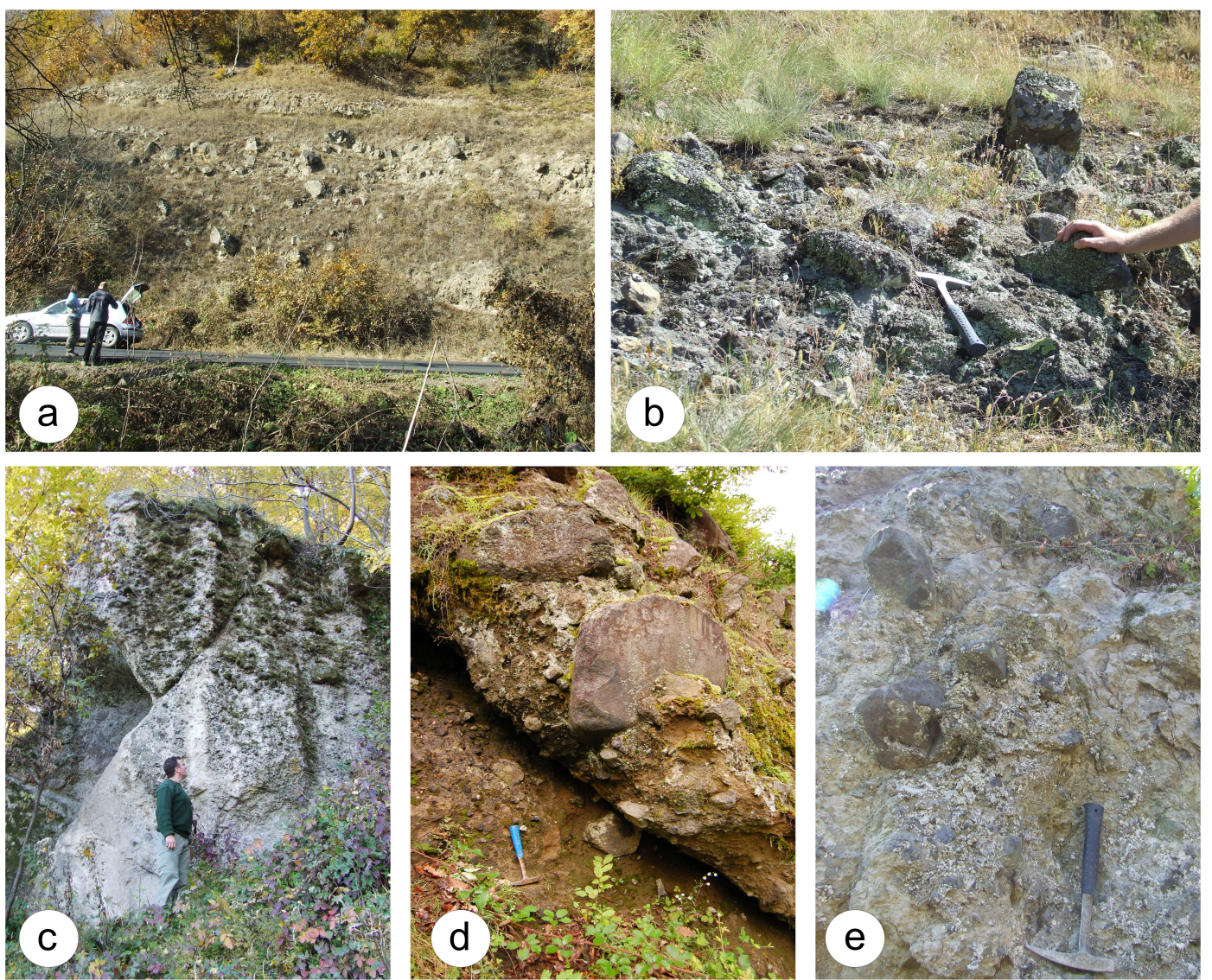

Fig. 3. Pictures of the selected studied outcrops of volcaniclastic rocks, of a matrix-supported type, with a rough stratification $(a, c)$ and consisting of unsorted angular andesitic clasts, embedded in a matrix of the same composition $(b, d, e)$. 

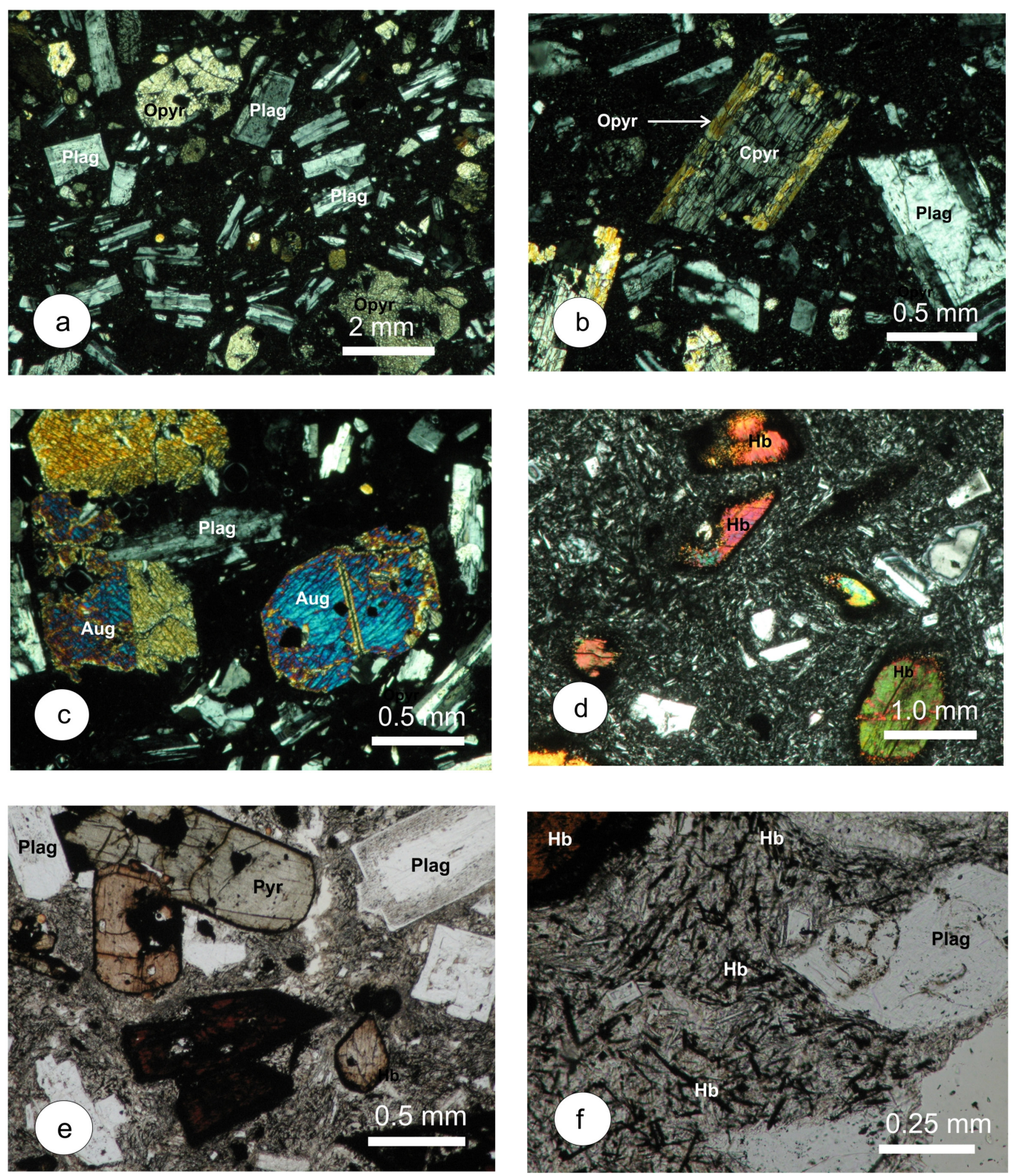

Fig. 4. Polarized light microphotographs of investigated volcanic clasts: a) Phenocrysts of orthopyroxene (Opyr) and plagioclase feldspars (Plag) in pyroxene andesite (crossed polars); b) Phenocrysts consisting of orthopyroxene core (Opyr) with a rim of overgrown clinopyroxene (Cpyr) (crossed polars); c) Twinned augite (Aug) in pyroxene andesite (crossed polars); d) Phenocryst of amphibole (Hornblende-Hb) with opacitized rim in amphibole-pyroxene andesite (crossed polars); e) Pyroxene (Pyr) phenocrysts with opacitized rim in amphibole-pyroxene andesite (parallel polars); f) Neddles of opacitized amphibole (Hb) in the groundmass of the amphibole-pyroxene andesite (parallel polars).

amphibole-pyroxene andesites. Both types are characterised by a porphyritic texture, with abundant phenocrysts of plagioclase feldspar, ortho- and clinopyroxene, amphibole (hornblende) and rare crystals of biotite, embedded in a microcrystalline or intergranulare groundmass, in some cases with hyalopilitic aspects. Overgrown clinopyroxene rims on orthopyroxene cores were observed in case of the pyroxene andesite (Fig. 4b). Frecvently, the phenocrysts of amphibole and more rare phenocrysts of pyroxene as well as biotite are affected by opacitization and the resulted opaque minerals are developed as a rim around the primary crystals (Fig. 4d-e). The small needle-like crystals of amphibole in the groundmass are entirely substituted by opaque minerals (Fig. 4f). The glass of the groundmass is frequently chloritized and shows an opaque appearance.

\section{Geochemical analyses}

Eighteen clasts from the investigated volcaniclastic deposits were selected (Fig. 2), the samples being chipped by hand and the weathered parts being carefully removed. The fresh rock was crushed using a jaw crusher, the obtained material being split by quartering until the necessary quantity was obtained and eventually finely grounded in an agate disk swing mill at the Department for Lithospheric Research, University of Vienna, Austria. The chemical composition was determined at ACME Analytical Laboratories Ltd, Vancouver (Canada). For major elements, X-ray fluorescence spectrometry on fusion glass disks prepared from a mixture of sample and lithium metaborate was used. Trace (including rare earth) elements were measured by inductively coupled plasma-mass spectrometry following lithium borate fusion 
and dilute acid digestion of sample pulps. Accuracy for all determinations is within $1 \%$ for major elements and within $3-5 \%$ for most of the trace elements.

\section{RESULTS}

\section{Major oxides}

The investigated rock samples are homogenous with respect to their major oxides composition (Table 1). The $\mathrm{SiO}_{2}$ content ranges from 55.26 to $59.68 \mathrm{wt} . \%$, while the $\mathrm{MgO}$ one between 2.69 and 5.08 wt. $\%$. The $\mathrm{Al}_{2} \mathrm{O}_{3}$ varies from 16.18 to 18.67 wt. $\%$, and the alkalies $\left(\mathrm{Na}_{2} \mathrm{O}+\mathrm{K}_{2} \mathrm{O}\right)$ from 3.53 wt. $\%$ şi
4.46 wt.\%. Some major oxides, such as $\mathrm{TiO}_{2}, \mathrm{Fe}_{2} \mathrm{O}_{3}, \mathrm{MgO}$ or $\mathrm{CaO}$, show a more or less pronounced negative correlation with $\mathrm{SiO}_{2}$, while of the alkalies, only $\mathrm{K}_{2} \mathrm{O}$ displays a positive correlation with $\mathrm{SiO}_{2}$ (Fig. 5). According to the total alkali versus silica content diagram (TAS, Le Bas et al., 1986), the investigated clasts from the studied area correspond mainly to the andesitic petrochemical type, and only two samples plot in the basaltic andesite field (Fig. 6). They have a calc-alkaline character and a medium K-content (Fig. 7). The data provided by this study are extremely similar to those published by Roșu et al. (2004) and Seghedi et al. (2010) for samples belonging to the Zărand area (Table 2).

Table 1. Whole rock major and trace element geochemical data for studied volcaniclastic rocks.

\begin{tabular}{|c|c|c|c|c|c|c|c|c|c|c|c|c|c|c|c|c|c|c|}
\hline Sam & B2 & B3 & B3a & B7 & B3b & B8 & B9 & AB2 & B4c & B5a & B10 & B6a & B6b & A7a & A7b & $\mathbf{A 3}$ & A4 & A6 \\
\hline \multicolumn{19}{|c|}{ Major oxides (wt.\%) } \\
\hline $\mathrm{SiO}_{2}$ & 8.47 & 7.44 & 58.48 & 8.57 & 6.71 & 59.12 & 58.77 & 57.04 & \begin{tabular}{|l|l|}
55.26 \\
\end{tabular} & 57.65 & 5.77 & 94 & 20 & 4 & 53 & 68 & 6.69 & 7.32 \\
\hline $\mathrm{Al}_{2} \mathrm{O}_{3}$ & 7.90 & 17.71 & 18.20 & 17.99 & 16.18 & 17.84 & 18.16 & 16.29 & 18.57 & 17.91 & 17.98 & 18.53 & 17.63 & 18.39 & 18.15 & 17.58 & 17.76 & 18.26 \\
\hline $\mathrm{Fe}_{2} \mathrm{O}_{3}$ & 6.97 & 7.49 & 7.31 & 7.33 & 7.81 & 7.17 & 6.62 & 7.64 & 8.28 & 7.59 & 8.37 & 7.44 & 7.11 & 7.71 & 7.64 & 6.61 & 8.39 & 7.52 \\
\hline MnO & 0.10 & 0.15 & 0.14 & 0.15 & 0.15 & 0.14 & 0.10 & 0.15 & 0.14 & 0.16 & 0.16 & 0.14 & 0.14 & 0.15 & 0.15 & 0.14 & 0.14 & 0.15 \\
\hline MgO & 2.69 & 3.47 & 3.02 & 3.14 & 5.08 & 3.06 & 2.81 & 4.88 & 3.59 & 3.50 & 4.00 & 2.97 & 2.94 & 3.10 & .05 & 2.70 & 3.05 & 2.98 \\
\hline $\mathrm{CaO}$ & 7.12 & 7.66 & 7.58 & 7.52 & 8.33 & 7.39 & 7.03 & 8.26 & 8.34 & 7.62 & 8.23 & 7.92 & 7.15 & 7.86 & 7.75 & 7.06 & 7.80 & 7.89 \\
\hline $\mathrm{Na}_{2} \mathrm{O}$ & 3.18 & 2.74 & 2.78 & 2.72 & 2.55 & 2.69 & 3.06 & 2.62 & 2.96 & 2.82 & 2.92 & 3.03 & 3.14 & 3.00 & 2.92 & 2.91 & 3.01 & 3.08 \\
\hline $\mathrm{K}_{2} \mathrm{O}$ & 1.23 & 1.12 & 0.84 & 0.84 & 1.07 & 0.84 & 1.05 & 1.11 & 0.79 & 1.06 & 0.73 & 0.79 & 1.32 & 0.82 & 0.79 & 1.36 & 0.76 & 0.77 \\
\hline $\mathrm{TiO}_{2}$ & 0.82 & 0.77 & 0.69 & 0.70 & 0.69 & 0.67 & 0.82 & 0.69 & 0.86 & 0.78 & 0.83 & 0.76 & 0.76 & 0.77 & 0.76 & 0.66 & 0.80 & 0.75 \\
\hline $\mathrm{P}_{2} \mathrm{O}_{5}$ & 0.19 & 0.17 & 0.16 & 0.17 & 0.23 & 0.17 & 0.16 & 0.24 & 0.22 & 0.17 & 0.22 & 0.22 & 0.21 & 0.22 & 0.22 & 0.20 & 0.22 & 0.22 \\
\hline LOI & - & 1.1 & 0.7 & 0.7 & 1.0 & 0.8 & 1.3 & 0.9 & 0.8 & 06 & 0.6 & .1 & 1.2 & 1.0 & 9 & 0.9 & 1.2 & .9 \\
\hline Total & \begin{tabular}{|l|}
99.82 \\
\end{tabular} & 99.84 & 99.86 & 99.86 & \begin{tabular}{|l|}
99.82 \\
\end{tabular} & 99.87 & 99.82 & 99.83 & \begin{tabular}{|l|l|}
99.83 \\
\end{tabular} & 99.84 & \begin{tabular}{|l|}
99.84 \\
\end{tabular} & 99.85 & 99.83 & \begin{tabular}{|l|l|}
99.84 \\
\end{tabular} & 99.85 & 99.83 & 99.84 & 99.85 \\
\hline \multicolumn{19}{|c|}{ Trace elements (ppm) } \\
\hline $\mathbf{R b}$ & 33.4 & 23.4 & 24.3 & 23.3 & 26.6 & 23.2 & 20.7 & 27.1 & 18.2 & 23.6 & 20.1 & 20.6 & 33.2 & 19.9 & 19.4 & 47.9 & 13.9 & 20.4 \\
\hline $\mathbf{B a}$ & 275 & 176 & 163 & 164 & 214 & 166 & 295 & 220 & 160 & 188 & 159 & 180 & 262 & 195 & 191 & 283 & 190 & 194 \\
\hline Nb & 6.0 & 4.5 & 3.4 & 4.2 & 3.6 & 3.7 & 5.6 & 3.8 & 4.1 & 4.1 & 3.2 & 2.8 & 4.6 & 3.3 & 3.2 & 5.5 & 3.6 & 4.0 \\
\hline $\mathrm{Sr}$ & 299.5 & 290.5 & 275.7 & 281.0 & 385.2 & 266.7 & 290.5 & 375.9 & 335.7 & 289.9 & 329.8 & 335.3 & 311.3 & 338.7 & 327.2 & 404.8 & 385.2 & 392.3 \\
\hline $\mathbf{V}$ & & 185 & 148 & 147 & & & & & 212 & & & & & 156 & 145 & 141 & 5 & 50 \\
\hline $\mathbf{Y}$ & 21.8 & 25.2 & 21.9 & 23.2 & 21.6 & 21.6 & 34.9 & 21.2 & 26.4 & 24.7 & 24.2 & 24.0 & 25.4 & 25.2 & 24.1 & 23.3 & 24.5 & 23.2 \\
\hline Ta & 0.4 & 0.3 & 0.3 & 0.3 & 0.3 & 0.3 & 0.4 & 0.3 & 0.3 & 0.2 & 0.3 & 0.2 & 0.3 & 0.3 & 0.3 & 0.4 & 0.3 & 0.2 \\
\hline Hf & & 2.9 & & 2.0 & & & 2.6 & & 2.1 & & & & & & .5 & & J.2 & .7 \\
\hline $\mathrm{Zr}$ & 115.5 & 96.3 & 88.3 & 95.2 & 91.5 & 90.8 & 112.7 & 87.9 & 86.4 & 93.1 & 82.6 & 97.6 & 116.1 & \begin{tabular}{|l|l}
101.9 \\
\end{tabular} & 97.5 & 121.2 & 104.5 & 100.1 \\
\hline Th & 4.3 & 2.9 & 2.7 & 2.9 & 3.5 & 2.6 & 4.4 & 34 & 3.1 & 31 & 2.7 & 3.3 & 4.2 & 3.3 & 3.3 & 4.8 & 3.5 & 3.5 \\
\hline $\mathbf{U}$ & & 1.0 & 0.7 & 0.6 & 0.9 & 0.7 & 1.3 & 1.0 & 0.7 & 0.9 & 0.5 & 0.6 & 1.0 & 0.7 & 0.6 & 1.5 & 0.6 & 0.9 \\
\hline Co & 15.5 & 17.9 & 15.4 & 15.2 & 23.7 & 14.5 & 12.8 & & 19.2 & 16.4 & 19.5 & 15.8 & 14.3 & 14.9 & 13.8 & 14.1 & 17.5 & 16.7 \\
\hline Cs & 0.4 & 0.6 & 0.5 & 0.4 & 0.8 & 0.5 & 0.5 & 0.8 & 0.2 & 0.5 & 0.4 & 0.4 & 1.0 & 0.5 & 0.3 & 1.2 & 0.3 & 0.5 \\
\hline Sc & 20 & 21 & 17 & 18 & 27 & 17 & 19 & 26 & 23 & 21 & 23 & 15 & 15 & 17 & 16 & 14 & 17 & 15 \\
\hline $\mathrm{La}$ & 14.5 & 10.5 & 9.2 & 9.8 & 12.2 & 9.5 & 17.6 & 12.0 & 11.7 & 10.1 & .4 & 11.3 & 14.8 & 11.8 & 11.5 & 6.9 & 12.2 & 12.5 \\
\hline $\mathrm{Ce}$ & 30.7 & 23.3 & 19.5 & 22.0 & 26.6 & 21.4 & 36.2 & 25.7 & 26.4 & 23.1 & 21.7 & 25.3 & 31.9 & 25.4 & 24.8 & 36.1 & 27.0 & 27.4 \\
\hline $\operatorname{Pr}$ & 4.03 & 3.17 & 2.77 & 2.87 & 3.47 & 2.81 & 4.81 & 3.41 & 3.61 & 3.13 & 2.94 & 3.39 & 4.13 & 3.47 & 3.38 & 4.06 & 3.26 & 3.34 \\
\hline Nd & 17.0 & 13.5 & 12.0 & 12.1 & 14.7 & 12.5 & 19.9 & 14.3 & 17.0 & 13.9 & 11.6 & 13.9 & 16.1 & 15.2 & 14.7 & 18.2 & 13.9 & 15.1 \\
\hline Sm & 3.79 & 3.32 & 2.86 & 3.11 & 3.37 & 2.92 & 4.34 & 3.30 & 3.91 & 3.39 & 3.31 & 3.48 & 4.14 & 3.50 & 3.53 & 3.58 & 3.16 & 3.47 \\
\hline $\mathbf{E u}$ & 1.13 & 0.99 & 0.93 & 1.00 & 1.01 & 0.93 & 1.22 & 0.98 & 1.13 & 0.99 & 1.01 & 1.09 & 1.11 & 1.10 & 1.07 & 1.05 & 1.12 & 1.04 \\
\hline Gd & 4.11 & 3.83 & 3.32 & 3.47 & 3.45 & 3.30 & 4.79 & 3.36 & 4.45 & 3.94 & 3.81 & 3.80 & 4.37 & 4.09 & 3.94 & 3.72 & 3.60 & 3.60 \\
\hline Tb & 0.63 & 0.69 & 0.56 & 0.62 & 0.60 & 0.60 & 0.82 & 0.57 & 0.73 & 0.66 & 0.66 & 0.63 & 0.69 & 0.65 & 0.63 & 0.69 & 0.66 & 0.66 \\
\hline Dy & 4.05 & 4.36 & 3.55 & 3.95 & 3.49 & 3.62 & 5.48 & 3.50 & 4.43 & 4.12 & 4.09 & 4.29 & 4.14 & 4.24 & 3.87 & 3.74 & 4.39 & 3.95 \\
\hline Ho & 0.83 & 0.93 & 0.77 & $\begin{array}{l}0.82 \\
\end{array}$ & 0.75 & 0.83 & 1.17 & 0.73 & 1.03 & 0.91 & 0.88 & 0.79 & 0.92 & 0.90 & 0.87 & 0.88 & 0.95 & 0.86 \\
\hline $\mathbf{E r}$ & 2.31 & 2.79 & 2.27 & 2.31 & 2.11 & 2.17 & 3.71 & 2.12 & 2.68 & 2.64 & 2.47 & 2.43 & 2.76 & 2.55 & 2.47 & 2.37 & 2.67 & 2.79 \\
\hline $\mathbf{T m}$ & 0.33 & 0.42 & 0.37 & 0.36 & 0.32 & 0.37 & 0.56 & 0.36 & 0.39 & 0.41 & 0.39 & 0.36 & 0.39 & 0.38 & 0.38 & 0.39 & 0.39 & 0.38 \\
\hline $\mathbf{Y b}$ & 2.01 & 2.57 & 2.02 & 2.52 & 2.03 & 2.36 & 3.52 & 1.99 & 2.76 & 2.52 & 2.50 & 2.42 & 2.65 & 2.46 & 2.43 & 2.52 & 2.52 & 2.44 \\
\hline $\mathbf{L u}$ & 0.33 & 0.43 & 0.36 & 0.38 & 0.34 & 0.36 & 0.63 & 0.35 & 0.40 & 0.42 & 0.41 & 0.40 & 0.42 & 0.40 & 0.39 & 0.42 & 0.40 & 0.40 \\
\hline
\end{tabular}


Table 2. Whole rock major and trace element compositional ranges for Neogene volcanic rocks in the study area, Bontău volcano, Zărand basin and the Apuseni Mts.

\begin{tabular}{|c|c|c|c|c|}
\hline $\begin{array}{l}\text { Sample } \\
\text { aria }\end{array}$ & $\begin{array}{l}\text { Volcanic clasts } \\
\text { (this study) }\end{array}$ & $\begin{array}{c}\text { Bontău volcano } \\
\text { (Seghedi et al., 2010) }\end{array}$ & $\begin{array}{c}\text { Zărand volcanics } \\
\text { (Roşu et al., 2004; Seghedi } \\
\text { et al., 2010) }\end{array}$ & $\begin{array}{c}\text { Apuseni Mts. } \\
\text { (Roşu et al., 2004; } \\
\text { Seghedi et al., 2010) }\end{array}$ \\
\hline \multicolumn{5}{|c|}{ Major oxides (wt.\%) } \\
\hline $\mathrm{SiO}_{2}$ & $55.26-59.68$ & $56.99-60.00$ & $56.99-60.56$ & $54.71-60.56$ \\
\hline $\mathrm{Al}_{2} \mathrm{O}_{3}$ & $16.18-18.57$ & $15.50-18.20$ & $15.50-18.48$ & $15.57-19.18$ \\
\hline $\mathrm{Fe}_{2} \mathrm{O}_{3}$ & $6.61-8.39$ & $6.50-8.40$ & $6.50-8.40$ & $4.04-8.40$ \\
\hline $\mathrm{MnO}$ & $0.10-0.16$ & $0.09-0.20$ & $0.09-0.20$ & $0.06-0.24$ \\
\hline MgO & $2.69-5.08$ & $1.80-6.40$ & $1.80-6.40$ & $1.50-6.40$ \\
\hline $\mathrm{CaO}$ & $7.03-8.34$ & $5.40-8.70$ & $5.40-8.70$ & $5.16-9.71$ \\
\hline $\mathrm{Na}_{2} \mathrm{O}$ & $2.55-3.18$ & $2.78-3.40$ & $2.78-3.40$ & $2.73-4.55$ \\
\hline $\mathrm{K}_{2} \mathrm{O}$ & $0.73-1.36$ & $0.83-1.16$ & $0.83-1.31$ & $0.74-5.32$ \\
\hline $\mathrm{TiO}_{2}$ & $0.66-0.86$ & $0.64-0.96$ & $0.64-0.96$ & $0.44-0.96$ \\
\hline $\mathbf{P}_{2} \mathbf{O}_{5}$ & $0.16-0.25$ & - & $0.18-0.23$ & $0.12-0.71$ \\
\hline LOI & $0.6-1.3$ & - & $0.21-0.44$ & $0.21-2.89$ \\
\hline Total & 99.82-99.87 & - & 99.44-100.38 & 97.08-100.80 \\
\hline \multicolumn{5}{|c|}{ Trace elements (ppm) } \\
\hline $\mathbf{N i}$ & - & - & $10.7-14.5$ & $3-56$ \\
\hline $\mathrm{Cr}$ & - & - & $18.7-30.8$ & $5-224$ \\
\hline $\mathbf{V}$ & $141-212$ & - & $142-209$ & $75.7-360$ \\
\hline Sc & $14-27$ & - & $17.7-26.5$ & $7-38.4$ \\
\hline $\mathbf{C u}$ & - & - & $38.8-95.3$ & $5-990$ \\
\hline $\mathbf{Z n}$ & - & - & $61.2-68.6$ & $35.5-91.4$ \\
\hline Ga & $15.60-18.70$ & - & 16.4-18 & $16-23.4$ \\
\hline $\mathbf{P b}$ & - & - & $3.9-6.6$ & $3-61.6$ \\
\hline $\mathrm{Sr}$ & $266.7-404.8$ & - & $249-354$ & $207-2770$ \\
\hline $\mathbf{R b}$ & $13.90-47.90$ & - & $33.6-44.4$ & $16-79$ \\
\hline $\mathbf{B a}$ & $159-295$ & - & $194-238$ & $181-2300$ \\
\hline $\mathbf{Z r}$ & $82.60-121.20$ & - & $110-127$ & $70.1-317$ \\
\hline $\mathbf{N b}$ & $2.80-6.00$ & - & $5.1-8$ & $5.1-29.8$ \\
\hline Th & $2.60-4.80$ & - & $3.9-4.7$ & $3-21.6$ \\
\hline $\mathbf{Y}$ & $21.20-34.90$ & - & $24.1-28.5$ & $15-32.1$ \\
\hline $\mathbf{L a}$ & $9.20-17.60$ & - & $11.4-14.4$ & 11-106 \\
\hline $\mathrm{Ce}$ & $19.50-36.20$ & - & $26.3-29.9$ & $24-205$ \\
\hline Nd & $11.60-19.90$ & - & $15.1-15.6$ & $12-66.7$ \\
\hline
\end{tabular}



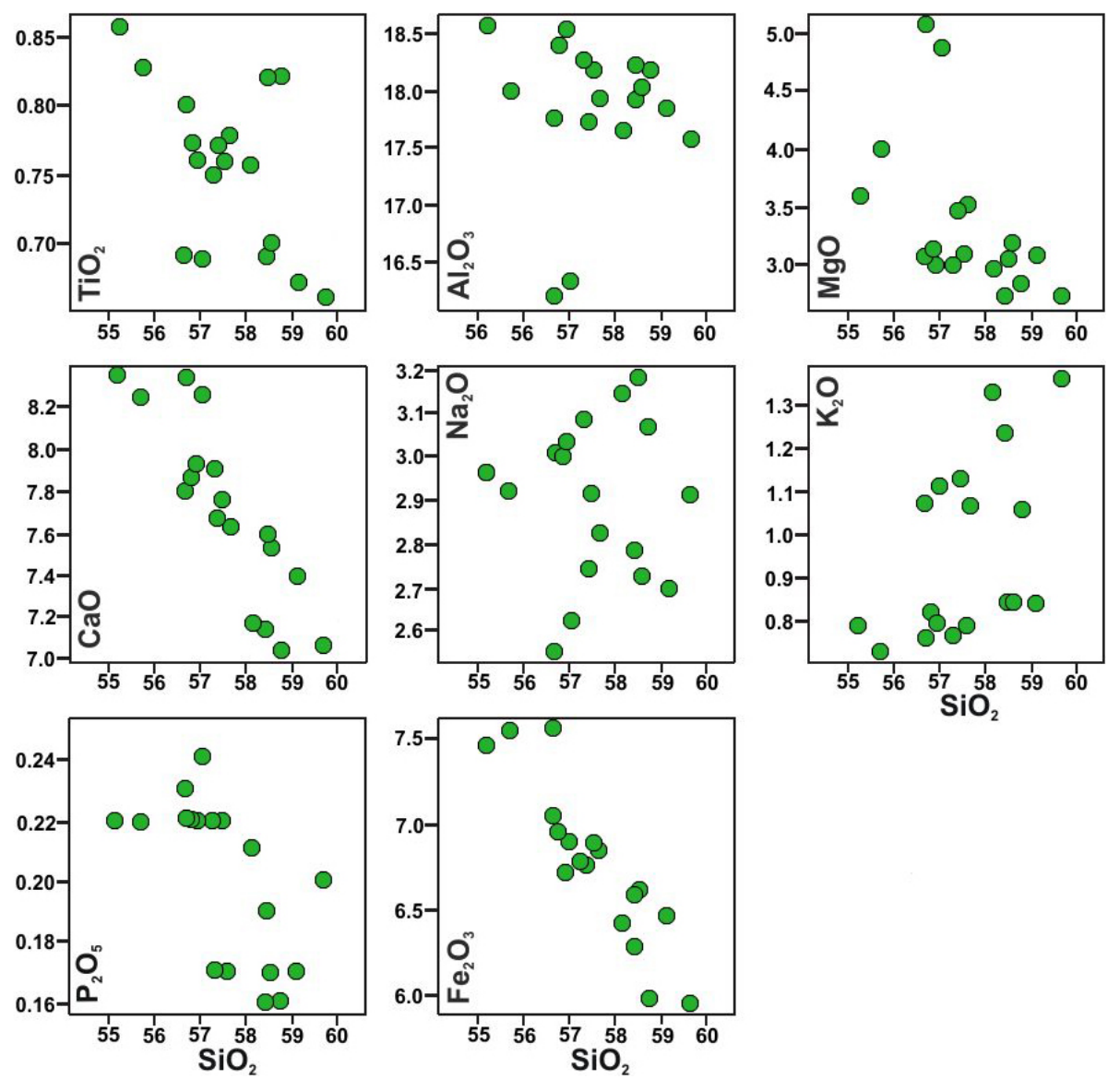

Fig. 5. Harker variation diagrams for major elements of the studied volcanic clasts. Green circles - investigated samples.

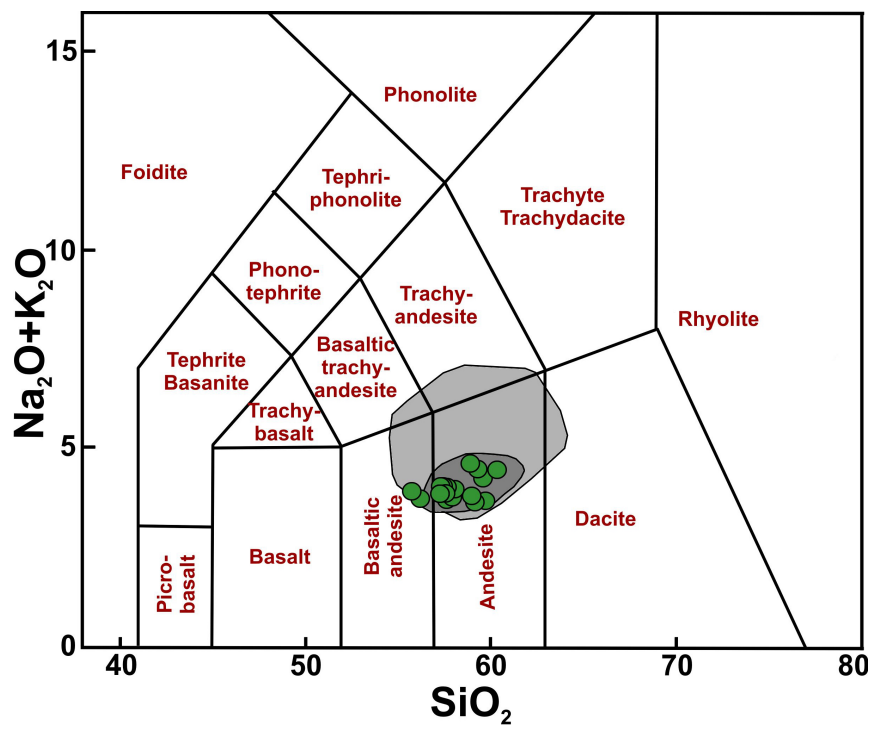

Fig. 6. TAS classification diagram of Le Bas et al. (1986) for the studied volcanic clasts. Green circles - investigated samples; light grey field-Neogene Apuseni magmatic rocks, excepting the 1.6 Ma old ones (from Roșu et al., 2004); dark grey field - Bontău volcanic rocks (from Seghedi et al., 2010).

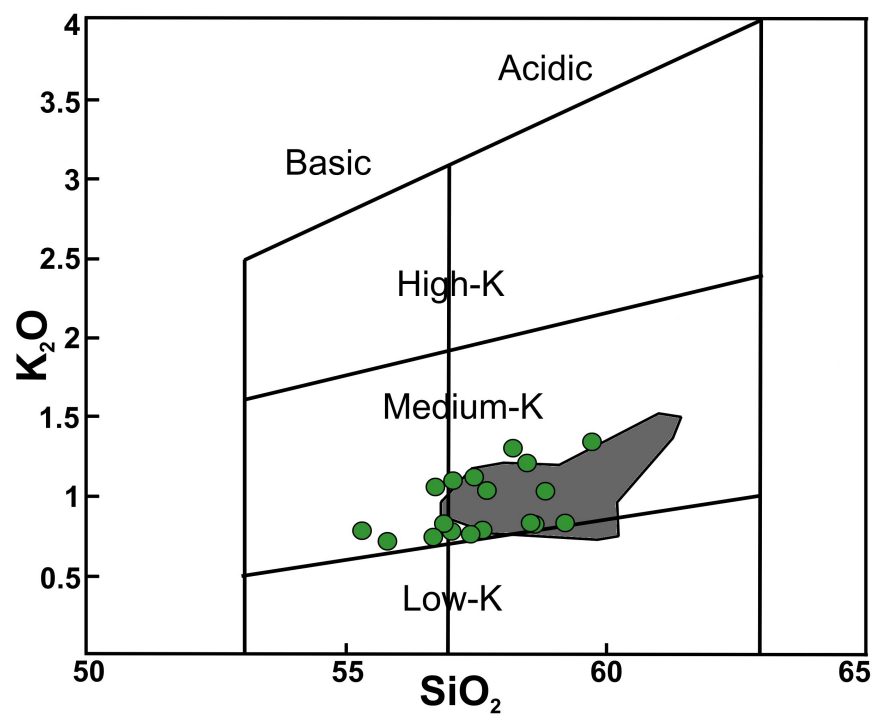

Fig. 7. $\mathrm{K}_{2} \mathrm{O}$ vs. $\mathrm{SiO}_{2}$ diagram of Peccerillo and Taylor (1976) for the investigated volcanic clasts. Green circles - investigated samples; dark grey field - Bontău volcanic rocks (from Seghedi et al., 2010). 


\section{Trace elements}

The High Field Strength elements (HFSE) content of the studied clasts varies in a very limited range: $\mathrm{Zr}=82.6-121.2$ ppm and $\mathrm{Nb}=2.8-6.06 \mathrm{ppm}$. The same narrow variation is characteristic also for the Large Ion Lithophile elements (LILE), such as $\mathrm{Sr}$ (226.7-404.8 ppm), Rb (13.9-47.9 ppm) and $\mathrm{Ba}$ (159-295 ppm) (Table 2).

All analyzed samples have a REE content which is varying in a narrow range of values: $\mathrm{La}=9.2-17.6 \mathrm{ppm}, \mathrm{Ce}=19.5-36.1$ ppm, $\mathrm{Pr}=2.77-4.81 \mathrm{ppm}, \mathrm{Nd}=11.6-19.9 \mathrm{ppm}, \mathrm{Sm}=2.86-4.34$ ppm, $\mathrm{Eu}=0.93-1.76 \mathrm{ppm}, \mathrm{Gd}=3.30-7.79 \mathrm{ppm}, \mathrm{Tb}=0.56-0.82$ ppm, Dy=3.50-5.48 ppm, Ho=0.73-1.17 ppm, Er=2.12-3.71 ppm, $\mathrm{Tm}=0.36-0.56 \mathrm{ppm}, \mathrm{Yb}=1.99-3.52 \mathrm{ppm}$ and $\mathrm{Lu}=0.35-$ $0.63 \mathrm{ppm}$. Thus, total REE content is relatively low, between 60.5 and $104.8 \mathrm{ppm}$ (Table 1).

\section{DISCUSSION}

\section{Geochemical characteristics of the studied samples}

Volcanism in the Zărand area evolved as part of the larger Neogene magmatic activity of the Apuseni Mts. Thus, geochemical data of investigated volcanic clasts had to be evaluated and interpreted also through comparison with other geochemical data of the related Neogene volcanic rocks in the Apuseni Mts.

The major element content of the investigated samples varies roughly within the same limits as those of the Apuseni Neogene volcanics (Roşu et al., 2004), although the $\mathrm{SiO}_{2}$ content is slightly lower than those of the samples from neighboring areas (57-60 wt.\%, Seghedi et al., 2010) (Table 2). Regarding the trace elements, both LILE and HFSE of the studied volcanic clasts have more limited variation ranges as compared with the calc-alkaline Neogene Apuseni magmatic rocks, most probably as a consequence of their respective spatial occurrences, restricted to the south-eastern part of Zărand volcanic area (Table 2).

A peculiar feature of the Apuseni Neogene volcanic rocks, as revealed by Roşu et al. (2004), is their separation in three different groups according to their $\mathrm{Zr}$ and especially $\mathrm{Nb}$ content. Although the studied samples have less $\mathrm{Nb}$ than the general Apuseni range (Table 2), they show clear affinities with the "low-Nb" group (Fig. 8). Another important characteristic of the Neogene magmatic rocks of the Apuseni Mts. is the occurrence of calc-alkaline rocks with adakite affinities (Roşu et al., 2001, 2004), as pointed out by the high $\mathrm{Sr} / \mathrm{Y}$ ratio (Defant and Drummond, 1990). They are marking the evolution of magma characteristics from normal calcalkaline to alkaline. The investigated volcanic clasts have low $\mathrm{Sr} / \mathrm{Y}$ ratios, between 8.32 and 17.83 , these values keeping them in the field of the normal calc-alkaline rocks.

In the incompatible trace element diagram normalized to N-MORB values of Sun and McDonough (1989) (Fig. 9), the studied samples show enrichment in LILE (e.g., $\mathrm{Ba}, \mathrm{Rb}, \mathrm{Th}, \mathrm{U}, \mathrm{K}$ ) and light REE (LREE) relative to heavy REE (HREE), and a pronounced depletion of the high field strength elements (HFSE, e.g. Nb, Ta and Ti). These features are typical for volcanic rocks generated in subduction-related or post-collisional settings (Wilson, 1997).

\section{Implications for magma source}

The chondrite-normalized REE spectrum displays a relatively slightly concave pattern (Fig. 10), with LREE enrichment as compared with HREE, and a very weak negative $\mathrm{Eu}$ anomaly. Such a distribution is very similar to the REE pattern reported by Roşu et al. (2004) for different andesitic rocks from Neogene volcanic areas of the Apuseni Mts. such as amphibole-pyroxene andesite from Poieniţa (Roşia Montană - Bucium - Baia de Arieş), pyroxene andesite from

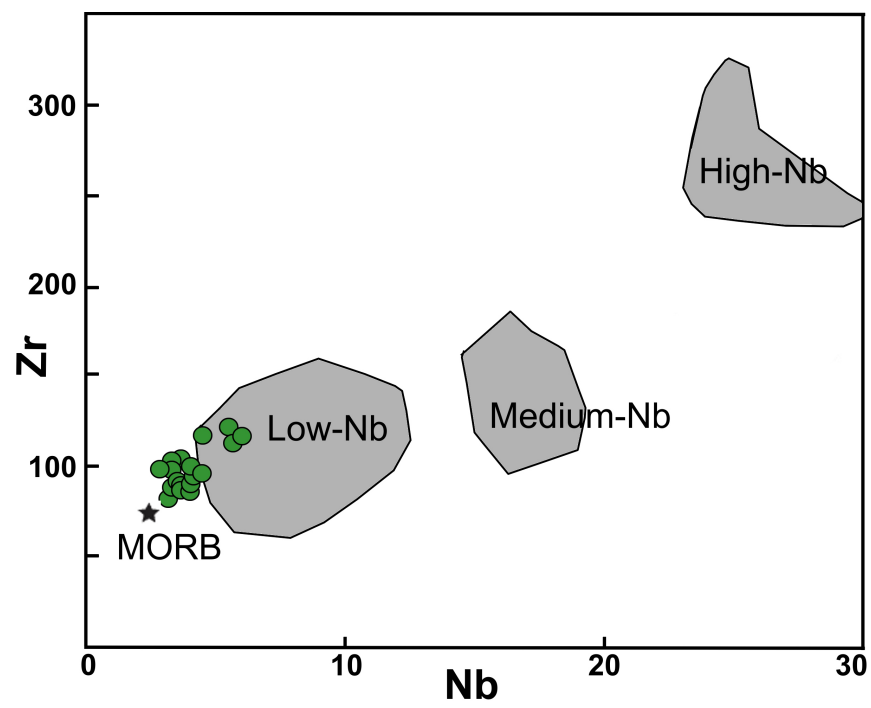

Fig. 8. $\mathrm{Zr}$ vs. $\mathrm{Nb}$ diagram for investigated volcanic clasts. Green circles - investigated samples; grey fields - Neogene Apuseni magmatic rocks (from Roşu et al., 2004).

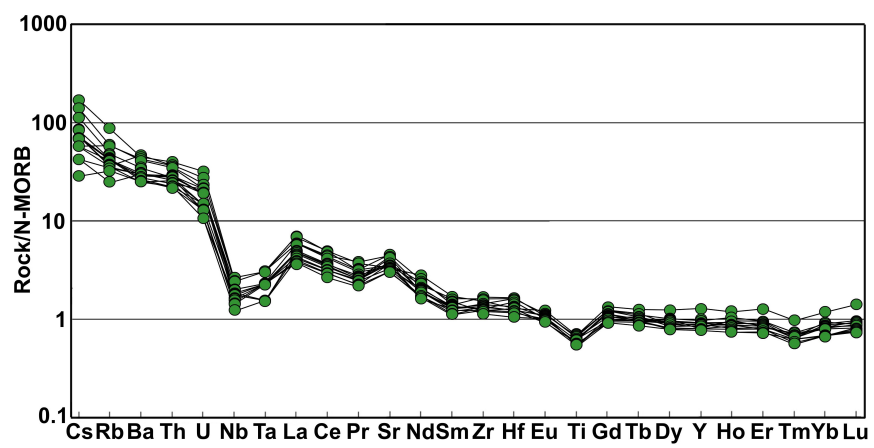

Fig. 9. $N$-MORB-normalized trace element diagram for the studied volcanic clasts. Green circles - investigated samples. Normalizing values are from Sun and McDonough (1989).

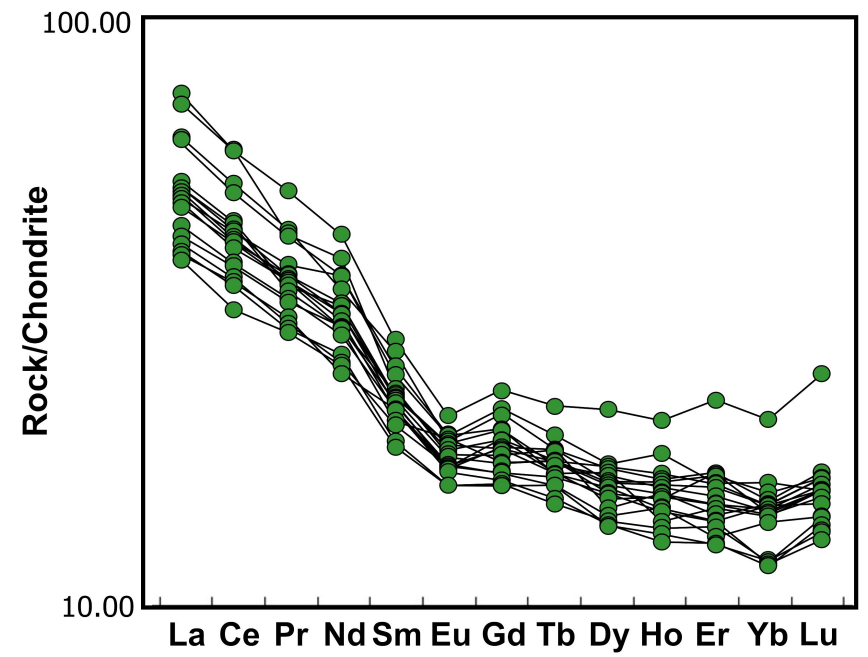

Fig. 10. Chondrite-normalized REE diagram for the studied volcanic clasts. Green circles - investigated samples. Normalizing values are from Sun and McDonough (1989). 
Citera (Roșia Montană - Bucium - Baia de Arieş), basaltic andesite from Detunata (Roşia Montană - Bucium - Baia de Arieş), quartz-bearing amphibole-pyroxene andesite from Brad (Brad-Săcărâmb) and pyroxene andesite from Chişindia (Zărand Basin). The enrichment of LREE is typical for mantle-derived magmas, and the slight negative Eu anomaly might indicate some plagioclase fractionation. Heavy REE of 10x chondritic concentration suggests that garnet is absent from the source (Wilson, 1997). Such geochemical pattern is due to the high values of the garnet/melt partition coefficient for andesitic liquids of the HREE which is varying from 1.520 for Eu to 57.00 for Lu (Irving and Frey, 1978).

As indicated by the low $\mathrm{Nb}$ content, the magma source was most probably located close to the boundary between the crust and the lithospheric mantle, similar to other Neogene magmatic rocks occurring in the Apuseni Mts. (Roşu et al., 2004). Minor fractional crystallization processes in crustal magma chambers is supported by the little variation of $\mathrm{SiO}_{2}$ content, as well as by the very weak negative $\mathrm{Eu}$ anomaly. This is due to the extensional setting in which the Apuseni Neogene volcanic products were emplaced, which did not favor long-stage magma chamber processes (Seghedi et al., 2010).

As in the whole Apuseni Mts., the studied samples of Neogene volcanic clasts display geochemical fingerprints typical for magmas generated by subduction processes, involving enrichment in incompatible elements such as Cs, $\mathrm{Ba}, \mathrm{Sr}$ or $\mathrm{U}$, and lack of enrichment in non-fluid-mobile elements such as $\mathrm{Nb}$, Ta and Ti (Fig. 9). In the Apuseni Mts., the enrichment in fluids of the magmas source during a previous geotectonic event was interpreted as causing the subduction signature in the Neogene magmatic rocks (especially for the $12 \mathrm{Ma}$ old and younger rocks) (Roşu et al., 2004). The Ba-La ratio of the investigated samples points out a slight enrichment in fluids, but in a much lesser extent as compared to other Neogene magmatic rocks occurring in the Apuseni Mts. (Fig. 11).

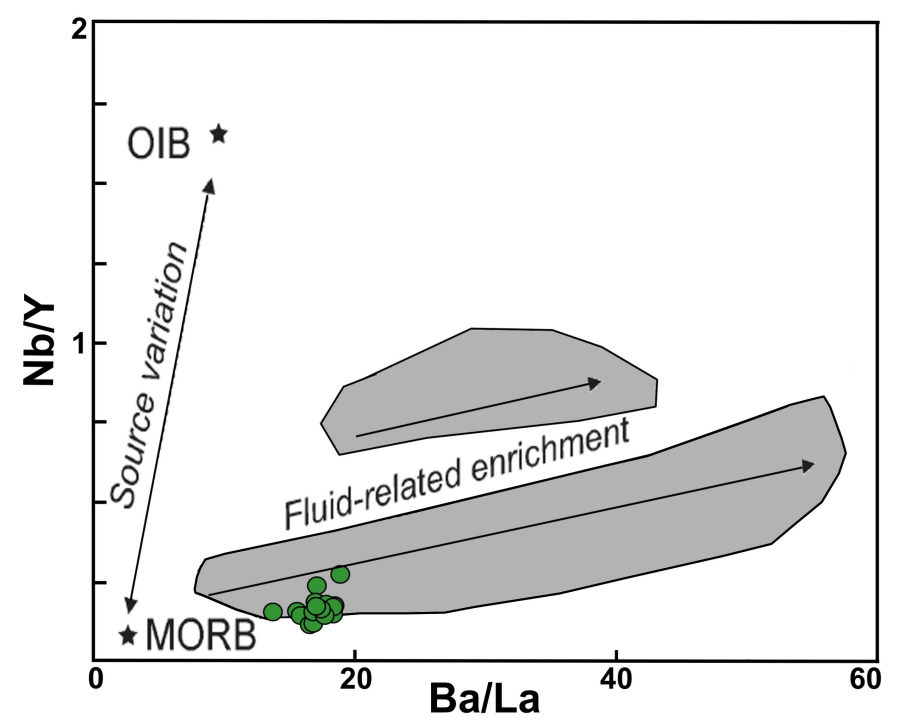

Fig. 11. $N b / Y$ vs. Ba/La diagram for the studied volcanic clasts. Green circles - investigated samples; grey fields - Neogene Apuseni magmatic rocks, excepting those 1.6Ma old (from Roşu et al., 2004). OIB (Ocean Island Basalt) and MORB (Middle Ocean Ridge Basalt) values are from Sun and McDonough (1989).

\section{Implications for the volcanic source area}

A composite volcanic structure located in the southeastern part of the Zărand Basin, named Bontău volcano, was described by Seghedi et al. (2010) (Fig. 2). Two different sub-aerial constructional phases were identified: the first one represented by lava flows and pyroclastic materials of pyroxene-andesite composition and the second one consisting of a succession of explosive eruptions generating pyroclastic rocks of amphibole-pyroxene andesite composition. The volcanic material was the source for debris flow deposits accumulated at the periphery of the primary pyroclastic deposits.

Petrographic features of the two types of andesitic rocks (pyroxene andesite and amphibole \pm pyroxene andesite) identified within studied volcaniclastic rocks are very similar to those of the Zărand basin (Roşu et al., 2004) and of the Bontău composite volcano (Seghedi et al., 2010). Also, a consistency of the geochemical characteristics was observed for the investigated samples and the other Zărand rocks, including the Bontău volcano (Table 2, Figs. 6, 7).

The studied andesitic volcaniclastic rocks have a rough stratification, striking $\mathrm{N}$ and NE with a dip slope up to $20 \%$ (Papiu, 1960). Also, east to the studied area (Fig. 2), very large blocks were mentioned, which were interpreted as an indicator of a close eruption center in the surroundings (Papiu, 1960), and which occur within the area where the first and second phase deposits of the Bontău volcano were noticed (Seghedi et al., 2010). The studied deposits are situated very close to the ring-plane association with distal epiclastic deposits associated with the terrestrial fluvial deposits developed in the western part of the Bontău volcano, at a distance between 7 and maximum $14 \mathrm{~km}$ from the volcano center (Fig. 2). Thus, the petrographical and chemical features, as well as the structural and spatial relationships, indicate a possible origin at the Bontău volcano for the investigated volcaniclastic deposits.

There are no radiometric age data for the studied volcanics. However, given the geochemical characteristics mentioned above, their spatial position within the Apuseni Mts, and even more, their possible genetic connection to the Bontău volcano, their age can be roughly presumed. They are located in the western part of the southern Apuseni Mts, related to the Zărand basin, in which the volcanic activity initiated around 13.4-12.4 Ma and then shifted towards the east (Roşu et al., 2004). The studied volcanics are surrounded by rocks dated 13.8-12.8 Ma in their western and northern part (Miniș area, Roşu et al., 2004) and 13.8-10 Ma in the east (Bontău volcano, Zărand Mts., Seghedi et al., 2010). Thus, for the studied volcanics, a similar age range, of 13.8 down to $10 \mathrm{Ma}$, may reasonably be assumed.

\section{CONCLUSIONS}

The Neogene volcaniclastic deposits of the south-eastern part of Zărand Basin were for the first time investigated geochemically. The rocks are mainly pyroxene-bearing andesites, and, subordinately, amphibole-pyroxene andesites. Both petrographic types are similar in their major and trace element composition. The major oxide contents classified the investigated volcanic rocks as medium-K, calc-alkaline andesites. 
Using the geochemical features, comparisons of the investigated volcaniclastic rocks with Neogene magmatic rocks of the Southern Apuseni Mts, and, whenever possible, with Neogene volcanites from the Zărand area, were performed. There is an obvious similarity of the chemical composition between of the studied volcanic clasts and other volcanic rocks from the neighbouring Zărand occurrences, within the same restricted variation range of major oxides and trace elements content, as compared with the Neogene volcanic rocks of the Apuseni Mts. However, the investigated volcanic clasts display some particularities, such as the $\mathrm{Nb}$ content which is the lowest one reported up to now for the Apuseni volcanics of Neogene age.

Based on the major and trace elements geochemistry as well as the similarities with other Neogene volcanic rocks from Apuseni area, the magma source is presumed to have a garnet-free upper lithospheric mantle material involved. Such conditions indicate a source located close to the boundary between crust and lithospheric mantle, as inferred by Roşu et al. (2004). The slight $\mathrm{Eu}$ negative anomaly suggests also a minor fractional crystallization processes affecting the magma. A subduction signature was identified for the investigated samples, and was interpreted as being related to some enrichment in fluids during magma generation, as Roșu et al. (2004) stated previously.

The petrographic and geochemical similarities, as well as the spatial relationships, suggest that the clastic material of the investigated volcaniclastic deposit from the south-eastern part of Zărand basin most probably originated in the Bontău volcanic structure. According to the location and geochemical similarities, the age of the volcanic activity from the studied area was assumed to be between 13.8 and $10 \mathrm{Ma}$.

Acknowledgements. This paper is a result of a postdoctoral research made possible by the financial support of the Sectorial Operational Programme for Human Resources Development 2007-2013, co-financed by the European Social Fund, under the project POSDRU/159/1.5/S/133391 - "Doctoral and postdoctoral excellence programs for training highly qualified human resources for research in the fields of Life Sciences, Environment and Earth". The financial support of project PN II-RU-TE 313/2010 from CNCSIS-UEFISCSU (Romanian Ministry of Education and Research) is also acknowledged. The two reviewers, Ioan Seghedi and Alexandru Szakács, are thanked for critically reading the manuscript and suggesting substantial improvements.

\section{REFERENCES}

Balintoni, I., Vlad, S. 1998, Tertiary magmatism in the Apuseni Mountains and related tectonic setting. Studia UBB Geologia, IX: 1-11.

Balintoni, I., Balica, C., Cliveţi, M., Li, Q-L., Hann, H.P., Chen, F. \& Schuller, V. 2009, The emplacement age of the Muntele Mare Variscan granite (Apuseni Mountains, Romania). Geologica Carpathica, 60: 495-504. http://dx.doi.org/10.2478/v10096-009-0036-x

Berbeleac, I., David, M. \& Zămârcă, A. 1981, Petrological and petrochemical data on the Tertiary volcanics from the eastern part of the Zărand Mountains. Dări de Seamă ale Institutului de Geologie şi Geofizică, LXVIII: 27-46.
Berbeleac, I., Neacșu, V., Zămîrcă, A. \& Bratosin, I. 1992, Geochemistry and mineralogy of altered rocks and pyrites associated with the porphyry copper-gold mineralization of the Tertiary subvolcanic body from Tălagiu, Zarand Mountains. Romanian Journal of Mineral Deposits, 75: 55-64.

Berbeleac, I., Iliescu, D., Andrei, J., Ciuculescu, O. \& Ciuculescu, R. 1995, The relationship between alterations, porphyry copper-gold and base metal-gold hydrothermal vein mineralizations in Tertiary intrusions, Tălagiu area, Zarand Mountains. Romanian Journal of Mineral Deposits, 76: 31-39.

Ciobanu, C.L., Găbudeanu, B. \& Cook, N.J. 2004, Neogene ore deposits and metallogeny of the Golden Quadri-lateral, South Apuseni Mts., Romania. In: Au-Ag-Telluride Deposits of the Golden Quadrilateral, Apuseni Mts., Romania (N.J. Cook \& C.L. Ciobanu, Eds.). Guidebook of the International Field Workshop of IGCP project 486 Alba Iulia, Romania. IAGOD Guidebook Series, 12: 23-88.

Cioflica, G., Savu, H., Borcoș, M., Ștefan, A. \& Istrate, G., 1973, Alpine volcanism and metallogenesis in the Apuseni Mountains. Guide to Excursion $3 \mathrm{AB}$, Symposium on Volcanism and Metallogenesis. I.G.R., Bucharest, Romania. Cook, N.J., Ciobanu, C.L., Damian, G. \& Damian, F. 2004, Tellurides and sulphosalts from deposits in the Golden Quadrilateral. In: $A u-A g$-telluride Deposits of the Golden Quadrilateral, South Apuseni Mts., Romania (N.J. Cook \& C.L. Ciobanu, Eds.). Guidebook of the International Field Workshop of IGCP project 486, Alba Iulia, Romania. IAGOD Guidebook Series, 12: 111-144.

Csontos, L. 1995, Tertiary tectonic evolution of the IntraCarpathian area: a review. Acta Volcanologica, 7: 1-13.

Defant, M.J., Drummond, M.S. 1990, Derivation of slab arc magmas by melting of young subducted lithosphere. Nature, 347: 662-665. http://dx.doi.org/10.1038/347662a0

Harangi, S. 2001, Neogene magmatism in the AlpinePannonian Transition zone - a model for melt generation in a complex geodynamic setting. Acta Vulcanologica, 13: 1-11.

Harangi, S., Lenkey, L. 2007, Genesis of the Neogene to Quaternary volcanism in the Carpathian-Pannonian region: role of subduction, extension, and mantle plume. Geological Society of America Special Paper, 418: 67-90.

http://dx.doi.org/10.1130/2007.2418(04)

Harangi, S., Downes, H. \& Seghedi, I. 2006, TertiaryQuaternary subduction processes and related magmatism in Europe. In: European Lithosphere Dynamics (Gee, D.G., Stephenson, R.A., Eds.), Geological Society London Memoirs, 32: 167-190.

Harris, C.R., Pettke, T., Heinrich, C.A., Roşu E., Woodland, S. \& Fry, B. 2013, Tethyan mantle metasomatism creates subduction geochemical signatures in non-arc $\mathrm{Cu}-\mathrm{Au}-\mathrm{Te}$ mineralizing magmas, Apuseni Mountains (Romania). Earth and Planetary Science Letters, 366: 122-136. http://dx.doi.org/10.1016/j.eps1.2013.01.035

Irving, A.J., Frey, F.A. 1978, Distribution of trace elements between garnet megacrysts and host volcanic liquid of kimberlitic and rhyolitic composition. Geochimica and Cosmochimica Acta, 42: 771-787. http://dx.doi.org/10.1016/0016-7037(78)90092-3 
Le Bas, M.J., Le Maitre, R.W., Streckeisen, A. \& Zanettin, B. 1986, A chemical classification of volcanic rocks based on the total alkali silica diagram. Journal of Petrology, 27: 45-750.

Panaiotu, C. 1998, Paleomagnetic constraints on the geodynamic history of Romania. Reports on Geodesy (Monograph of Southern Carpathians), 7 (37): 49-71.

Papiu, V.C., 1960, Recherches géologique dans le Masif de Drocea. Annuaire du Comité Géologique, XXVI-XXVIII: $317-346$

Pătrașcu, S., Panaiotu, C., Șeclăman, M. \& Panaiotu, C.E. 1994, Timing of the rotational motion of Apuseni Mountains (Romania): paleomagnetic data from Tertiary magmatic rocks. Tectonophysics, 233: 163-176.

http://dx.doi.org/ 10.1016/0040-1951(94)90239-9

Peccerillo, A., Taylor, S.R. 1976, Geochemistry of Eocene calc-alkaline volcanic rocks from the Kastamonu Area, Northern Turkey. Contributions to Mineralogy and Petrology, 58: 63-81.

http://dx.doi.org/10.1007/BF00384745

Pécskay, Z., Edelstein, O., Seghedi, I., Szakács, A., Kovacs, M., Crihan, M. \& Bernard, A. 1995, K-Ar datings of Neogene-Quarternary calc-alkaline volcanic rocks in Romania. Acta Vulcanologica, 7: 53-61.

Pécskay, Z., Lexa, J., Szakács, A., Seghedi, I., Balogh, K., Konečný, V., Zelenka, T., Kovacs, M., Póka, T., Fülöp, A., Márton, E., Panaiotu, C. \& Cvetković, V. 2006, Geochronology of Neogene-Quaternary magmatism in the Carpathian arc and Intra-Carpathian area: a review. Geologica Carpathica, 57: 511-530.

Ratschbacher, L., Linzer, H-G., Moser, F., Strusievicz, R.O., Bedelean, H., Har, N., Mogos, A. 1993, Cretaceous to Miocene thrusting and wrenching along the Central South Carpathians due to a corner effect during collision and orocline formation. Tectonics, 12 (4): 855-873. http://dx.doi.org/10.1029/93TC00232

Roşu, E., Pécskay, Z., Ștefan, A., Popescu, G., Panaiotu, C. \& Panaiotu, C.E. 1997, The evolution of the Neogene volcanism in the Apuseni Mountains (Romania): constraints from new K-Ar data. Geologica Carpathica, 48: 353-359.

Roşu, E., Szakács, A., Downes, H., Seghedi, I., Pécskay, Z. \& Panaiotu, C. 2001, The origin of Neogene calc-alkaline magmatism and alkaline magmas in the Apuseni Mountains, Romania: The adakite connection. Romanian Journal of Mineral Deposits, 79 (1): 3-23.

Roşu, E., Seghedi, I., Downes, H., Alderton, D.H.M., Szakács, A., Pécskay, Z., Panaiotu, C., Panaiotu, E.C. \& Nedelcu, L. 2004, Extension-related Miocene calc-alkaline magmatism in the Apuseni Mountains, Romania: origin of magmas. Schweizerische Mineralogische und Petrographische Mitteilungen, 84: 153-172.

Sagatovici A., Anastasiu N. 1972, The study of pyroclastic rocks from Minişul de Sus (Bazinul Zărandului). Analele Universităţii Bucureşti, Geologie, XXI: 31-40 (in Romanian).
Savu, H., Neacşu, Gh. 1962, Neogene volcanism in the Zărand Basin. Dări de Seamă ale Şedinţelor, XLVII: 345-360 (in Romanian).

Schmid, S., Bernoulli, D., Fügenschuh, B., Maţenco, L., Schefer, S., Schuster, R., Tischler, M. \& Ustaszewski, K. 2008, The Alpine-Carpathian-Dinaridic orogenic system: correlation and evolution of tectonic units. Swiss Journal of Geosciences, 101: 139-183. http://dx.doi.org/10.1007/s00015-008-1247-3

Seghedi, I., Downes, H. 2011, Geochemistry and tectonic development of Cenozoic magmatism in the CarpathianPannonian region. Gondwana Research, 20: 655-672.

http://dx.doi.org/10.1016/j.gr.2011.06.009

Seghedi, I., Balintoni, I. \& Szakács, A. 1998, Interplay of tectonics and Neogene post-collisional magmatism in the Intracarpathian area. Lithos, 45: 483-499. http://dx.doi.org/10.1016/S0024-4937(98)00046-2

Seghedi, I., Downes, H., Szakács, A., Mason, P.R.D., Thirlwall, M.F., Roşu, E., Pécskay, Z., Márton, E. \& Panaiotu, C. 2004, Neogene - Quaternary magmatism and geodynamics in the Carpathian-Pannonian region: a synthesis. Lithos, 72: $117-146$

http://dx.doi.org/10.1016/j.lithos.2003.08.006

Seghedi, I., Downes, H., Harangi, Sz., Mason, P.R.D. \& Pécskay, Z. 2005, Geochemical response of magmas to Neogene-Quaternary continental collision in the Carpathian-Pannonian region: a review. Tectonophysics, 410: 485-499.

http://dx.doi.org/10.1016/j.tecto.2004.09.015

Seghedi, I., Szakács, A., Roşu, E., Pécskay, Z. \& Gméling, K. 2010, Note on the evolution of a Miocene composite volcano in an extensional setting, Zărand Basin (Apuseni Mts., Romania). Central European Journal of Geosciences, 2-3: 321-328 http://dx.doi.org/10.2478/v10085-010-0021-8

Sun, S.S., McDonough, W.F. 1989, Chemical and isotopic systematics of oceanic basalts: implication for mantle compositions and processes. Geological Society of London, Special Publication 42: 313-345. http://dx.doi.org/10.1144/GSL.SP.1989.042.01.19

Szabó, Cs, Harangi, Sz. \& Csontos, L. 1992, Review of Neogene and Quaternary volcanism of the CarpathianPannonian region. Tectonophysics, 208: 243-256. http://dx.doi.org/10.1016/0040-1951(92)90347-9

Szakács, A., Roşu, E., Downes, H., Seghedi, I. \& Pécskay, Z. 1999, Relation between geochemical features and age of the Neogene volcanic rocks in the Apuseni Mountains, Romania. Romanian Journal of Tectonics and Regional Geology, 77 (1): 36.

Udubaşa, G., Roşu, E., Seghedi, I. \& Ivăşcanu, M.P. 2001, The "Golden Quadrangle" in the Metaliferi Mountains, Romania: what does this really mean? Romanian Journal of Mineral Deposits, 79 (2): 24-34.

Wilson, M. 1997, Igneous Petrogenesis, a global tectonic approach. Chapman and Hall, London, 466 p. 